Australian Journal of

Crop Science

AJCS

AJCS 13(11):1892-1900 (2019)

ISSN:1835-2707

doi: 10.21475/ajcs.19.13.11.p1330

\title{
Evaluation of some bread wheat genotypes popular in Saudi Arabia under drought stress
}

\author{
Soleman M. Al-Otayk, Abdulrahman A. AL-Soqeer, Abd Elsalam M. Menshawy and Mohamed I. Motawei
}

Plant Production and Protection Dept., College of Agriculture and Veterinary Medicine, Qassim University, Saudi Arabia

*Corresponding author: rumotawei@hotmail.com

\begin{abstract}
Six bread wheat genotypes were evaluated in three separate irrigation regime experiments to compare the response of agronomic performance and to identify genotypes with high yield potential under drought stress. The first irrigation treatment (I3) was given normal water irrigation (about $7000 \mathrm{~m}^{3} \mathrm{ha}^{-1}$, according to recommendation for Qassim Region). The second (I2) and third (I1) treatments were given $2 / 3$ and $1 / 3$ of water amount of the first treatment, respectively. Factorial experiments in randomized complete block design with three replications were conducted during 2009/2010 and 2010/2011 seasons in the arid environment of central region of Saudi Arabia. Measurements were taken on days to heading, plant height, number of spikes $\mathrm{m}^{-2}$, number of kernels spike ${ }^{-1}$, 1000-kernel weight and grain yield. The drought susceptibility index (DSI) and water utilization efficiency (WUE) were calculated. The results revealed that effect of irrigation regime was highly significant for all traits, except days to heading. All studied characters were significantly decreased by reducing the amount of irrigation water. Grain yield showed maximum sensitivity as affected by moisturestress. Means over environments indicated the existence of sufficient genetic variability among the genotypes for all the characters studied. Giza 171 recorded the highest values for most yield characters, while genotype 'Sama' was the lowest for the most yield characters. Giza 171, Sakha 93 and IC-1 recorded highest grain yield and WUE, based on average over irrigation treatments. Giza 171, Sakha 93 and IC-2 can be considered as drought stress tolerant genotypes.
\end{abstract}

Keywords: Bread wheat, genotypes, irrigation, grain yield and yield components.

Introduction

Wheat is the most important cereal crop all over the world, and the main food in many parts of the world. Among all the stress factors either biotic or abiotic factors, drought plays a significant role for reduced wheat production and performance upon a great extent (Kamran, et al., 2014). Drought tolerance refers to ability of genotype to remain relatively more productive than other under limited condition. Breeders are always looking for drought tolerance germplasm. Evidences for inter- and intra-specific variation in drought tolerance were reported by many investigators (Shamsi et al., 2010; Jatoi et al., 2011; Sayyah et al., 2012; Mushekwa 2012; Ali et al., 2013; Andarab, 2013; Kamran et al., 2014). The evaluated genotypes were sometimes cultivars, lines and/or landraces (Ali et al., 2013; Kamran et al., 2014) while in others they were segregating and/or non-segregating populations (Ahmed et al. 2014). Many researchers have proven the importance of irrigation treatment to maximize wheat productivity (Khakwani et al., 2011; Mushekwa, 2012; Andarab, 2013). Grain yield, number of grains spike ${ }^{-1}$ and the number of spikes plant ${ }^{-1}$ showed maximum sensitivity as affected by water stress (Abd El-Moneim et al., 2010 and Ali et al., 2013). Andarab (2013) reported that we can consider plant height, grain weight and number of grains spike ${ }^{-1}$ as the criteria to select superior genotypes at an end-season drought condition. Karamanos et al. (2012) mentioned that plants show greater sensitivity to water stress during the differentiation of spikes. Moreover, Kamran et al. (2014) reported that, water stress at all stages of plant growth affects the grain yield. Numerous previous studies indicated the effects of water deficit on wheat plants as reduction in days to heading, plant height, grain yield and its components (Khakwani et al., 2011; Mushekwa, 2012; Andarab, 2013; Ali et al., 2013; Kamran et al., 2014). On the other hand, Tahmasebi et al. (2007) did not find any effect of water deficit on number of kernels per spike in wheat. Meanwhile, Okuyama et al. (2004) observed the same trend for kernel weight in first year of their studies.

Significant differences have been observed among in wheat genotypes for days to heading, plant height, yield and its components and WUE under normal and water stress conditions (Khakwani et al., 2011; Mushekwa, 2012; Ali et al., 2013). Significant genotype $\times$ environment interactions for most agronomic characters were found (Jatoi et al., 2011; Mushekwa, 2012; Ali et al., 2013).

Mushekwa (2012) and Bacon (2004) defined WUE as the ratio of net $\mathrm{CO}_{2}$ assimilation to water used, while $\mathrm{CO}_{2}$ assimilation may either be net $\mathrm{CO}_{2}$ exchange and economic yield. In wheat, 
the WUE decreases with increased irrigation times and amounts of irrigation water per growing season (Mensshawy and Hagrass, 2008; Miranzadeh et al. 2011; Mushekwa, 2012). Zhang et al. (2010) found variation in WUE for genotypes and suggested that genotypes with higher yield generally have higher WUE. Drought susceptibility index (DSI) is suggested as useful indicator for wheat breeding where the stress is severe (Akçura et al., 2011). Our objectives were to: (A) Compare the response of agronomic performance of 6-bread wheat genotypes under irrigation regime, (B) to identify and select some wheat genotypes with high yield potential under reduced irrigation and $(\mathrm{C})$ to determine the relative tolerance of wheat genotypes to drought stress.

\section{Results and Discussions}

\section{Effects of irrigation treatments}

The analysis of variance for all studied characters (Table 4) showed highly significant variations due to year. Therefore, the results are discussed in each year. Effects of irrigation treatments on studied characters of six bread wheat genotypes and their interactions in two seasons are presented in Tables 5-6. The water regime had highly significant effect on all parameters measured except days to heading in two seasons and kernel weight in the 1st season (Tables 5-6). Insignificant difference was observed for days to heading among irrigation treatments, one month after planting date, suggesting that environmental factors have little effect on this character during the vegetative stage. These results are in harmony with those reported by Menshawy and Hagras (2008) and Khakwani et al. (2011) who found non-significant effect of stress environments on days to $50 \%$ heading among wheat varieties. Pireivatlou and Yazdansepas (2008) reported that insignificant kernel weight could be due to a lower number of grains spike ${ }^{-1}$ in drought stress conditions, where assimilates were partitioned among less number of grains spike ${ }^{-1}$. Moreover, Mushekwa (2012) suggested that environmental factors have little effect on kernel weight. Water stress significantly reduced the plant height, number of spikes $\mathrm{m}^{-2}$, number of kernels spike $^{-1}$, kernel weight, grain yield and WUE. The 13 treatment recorded the highest values over all genotypes for all characters, compared to other irrigation treatments. Severe water stress (I1) had greater reduction in all components than moderate stress (12). Reduction was as much as in grain yield over severe water stress relative to the control treatment of both years ( 84.1 and $80.3 \%$, respectively) (Table 6). Grain yield showed maximum sensitivity as affected by moisture-stress, whereas grain weight showed the least sensitivity to moisture stress. These results coincide with the findings of Shamsi et al. (2010) who reported that compared to the control treatment, severe drought stress exhibited $85 \%$ reduction in grain yield. KulKarni et al. (2008) reported that crop yield is reduced by $70-80 \%$ due to a drought spell during the reproductive stage. Therefore, it has now become important to evaluate the new high yielding wheat varieties which are tolerant to the severe climatic conditions, especially drought (Mahmood et al., 2013). Fischer and Maurer (1978), Guttieri et al. (2001) and Zhang et al. (2006) observed that grains number spike ${ }^{-1}$ was reduced more compared to the other yield components when stress severity increased. Ehdaie et al. (1988) reported that number of grains spike ${ }^{-1}$ was the most affected yield component. Thompson and Chse (1992) displayed that reduced grain yield under moisture stress was a result of reduction in number of spikes $\mathrm{m}^{-2}$, grains number spike ${ }^{-1}$ and individual grain weight. Karamanos et al. (2012) explained that water shortage especially during the differentiation of spikes affects productivity because of inhibition of meiosis and photosynthesis leading to reduced number of spikelets and grains per ear, increased stomata resistance and reduced cell turgor and; therefore, cell growth. These findings for WUE are not in agreement with the results of many researchers (Menshawy and Hagrass, 2008; Balouchi, 2010; Mushekwa, 2012) who reported a higher WUE in water stress conditions. These differences could be attributed to different climatic and soil conditions, different methods of exercising water treatment, and different genotypes used in different experiments. Numerous previous studies indicated the effects of water stress on wheat plants as reduction in agronomic and yield and its components characters (Khakwani et al., 2011; Karamanos et al., 2012; Andarab 2013; Ali et al., 2013 and Kamran et al. 2014). Meanwhile, Okuyama et al. (2004) observed the same trend for kernel weight in one of the two years of their studies.

\section{Effect of wheat genotypes}

The results of ANOVA and means of genotypes indicated the existence of sufficient genetic variability among the six wheat genotypes for all the characters studied (Table 5-6). These variations among genotypes might reflect, partially, their different genetic backgrounds. Yecora Rojo was the earliest genotype in days to heading while, genotype 'Sama' was latest one. For plant height, Yecora Rojo was shortest genotype, while genotype 'Sama' was the tallest one (Table 5). Giza171 recorded the highest values of the most yield characters and WUE, while genotype 'Sama' was the lowest one for the most yield characters and WUE. The Giza171 cultivar showed significantly good performance for most yield characters than other wheat genotypes in the two seasons. Giza171, Sakha93 and IC-1 gave the highest grain yields among genotypes, representing the best performing genotypes at normal and stress conditions. Genotypes that recorded higher WUE were tended to have had higher grain yield.

Generally, yield components were higher in the 2nd season comparing to 1 st season. This may cause a higher grain yield in the 2 nd season. This was consistent with findings of Thompson and Chse (1992) who displayed that reduced grain yield under moisture stress was result of reduction in number of spikes $\mathrm{m}^{-2}$, grains number spike ${ }^{-1}$ and individual grain weight. Many researchers observed significant differences among wheat genotypes for days to heading, plant height and yield characters (Shamsi et al., 2010; Khakwani et al., 2011; Jatoi, et al., 2011; Karamanos et al., 2012; Mushekwa 2012; Andarab 2013; Ali et al., 2013 and Kamran et al. 2014). 
Table 1. Monthly mean air temperature $\left({ }^{\circ} \mathrm{C}\right)$, mean relative humidity $(\mathrm{RH} \%)$ and precipitation $(\mathrm{mm} / \mathrm{month})$ at the experimental sites in 2010 and 2011 seasons.

\begin{tabular}{|c|c|c|c|c|c|c|c|c|}
\hline \multirow[t]{3}{*}{ Month } & \multicolumn{4}{|c|}{ Mean air temperature ${ }^{\circ} \mathrm{C}$} & \multicolumn{2}{|c|}{ Mean RH \% } & \multicolumn{2}{|c|}{ Precipitation } \\
\hline & \multicolumn{2}{|l|}{2010} & \multicolumn{2}{|l|}{2011} & \multirow{2}{*}{2010} & \multirow{2}{*}{2011} & \multirow{2}{*}{2010} & \multirow{2}{*}{2011} \\
\hline & Min. & Max. & Min. & Max. & & & & \\
\hline Jan. & 8.4 & 23.3 & 8.5 & 20.7 & 58 & 67.8 & 2.7 & 28.0 \\
\hline Feb. & 10.9 & 27.1 & 10.8 & 24.6 & 46 & 50.2 & 1 & 0.0 \\
\hline Mar. & 13.3 & 31.4 & 12.3 & 26.6 & 35 & 39.1 & 0 & 1.0 \\
\hline Apr. & 18.9 & 34.5 & 17.9 & 32.3 & 48 & 45.9 & 27.9 & 26.0 \\
\hline May. & 24.1 & 39.9 & 24.6 & 40.0 & 34 & 29.1 & 16.4 & 0.0 \\
\hline
\end{tabular}

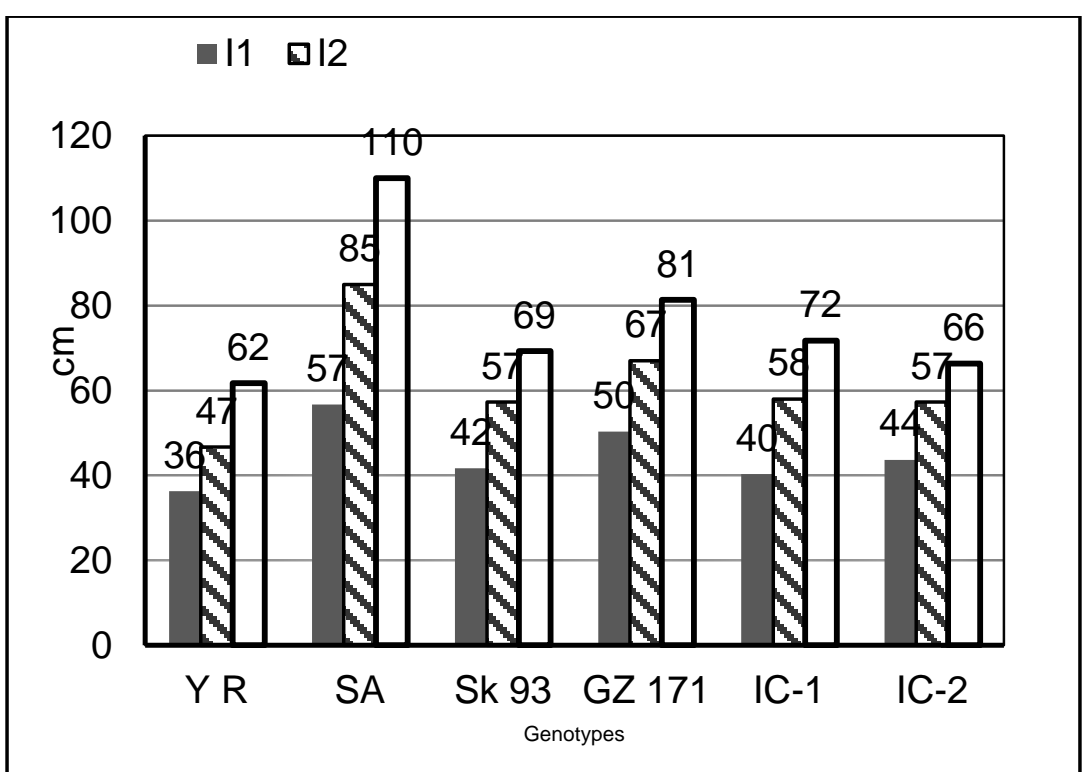

Fig 1. Plant hieght of six wheat genotypes as affected by irrigation regime in second season (LSD at $5 \%$ level for interaction, 9.8).

Table 2. The pedigree, abbreviation (Abr.) and origin of wheat genotypes under study.

\begin{tabular}{lll}
\hline Entry & Abr. & Source \\
\hline Yecora Rojo & YR & USA \\
Sama & SA & KSA \\
Sakha 93 & SK93 & Egypt \\
Giza 171 & GZ171 & Egypt \\
LFN/1158.57//PRL/3/HAHN/4/KAUZ/5/KAUZ.CMBW89Y1044-0TOPM-8Y-010M 020B- & IC-1 & ICARDA \\
ONPL-010Y-3M-015Y-OY-0AP & IC-2 & ICARDA \\
KAUZ/ STAR. CMBW90Y3180-74M-015Y-015M-1Y-0B-0AP & & \\
\hline
\end{tabular}

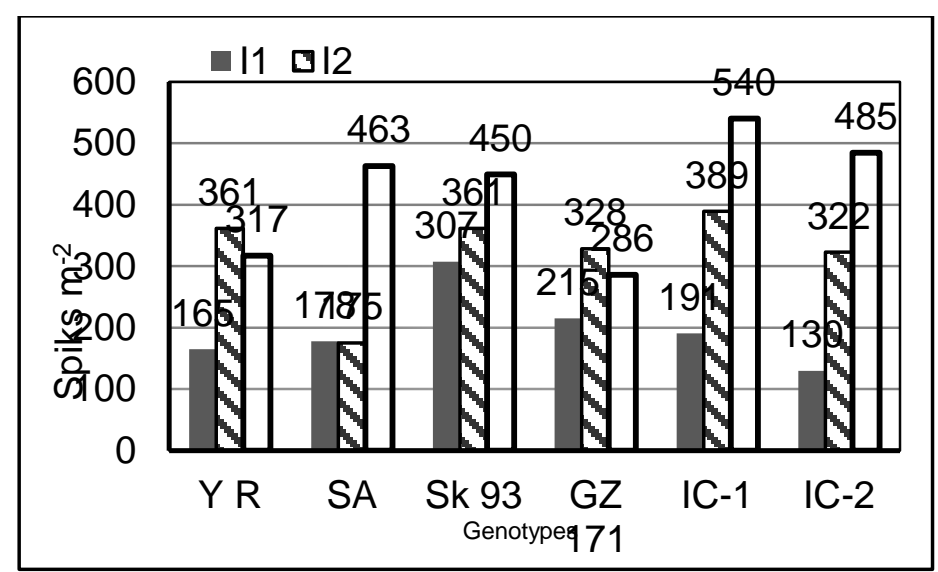

Fig 2. Spiks $\mathrm{m}^{-2}$ of six wheat genotypes as affected by irrigation regime in first season (LSD at $5 \%$ level for interaction, 118). 
Table 3. Amount of irrigation water, rainfall and seasonal water applied $\left(\mathrm{m}^{3} \mathrm{ha} \mathrm{h}^{-1}\right)$ delivered to each irrigation treatment during the two growing seasons, 2009/2010 and 2010/11.

\begin{tabular}{lllllll}
\hline & \multicolumn{5}{c}{$2009 / 10$} & \multicolumn{3}{c}{$2010 / 11$} \\
\cline { 2 - 7 } & $\mathrm{I}_{1}$ & $\mathrm{I}_{2}$ & $\mathrm{I}_{3}$ & $\mathrm{I}_{1}$ & $\mathrm{I}_{2}$ & $\mathrm{I}_{3}$ \\
\hline Irrigation water, $\left(\mathrm{m}^{3} \mathrm{ha}^{-1}\right)$ & 3040 & 4090 & 6040 & 3400 & 4572 & 6572 \\
Total rainfall, $\left(\mathrm{m}^{3} \mathrm{ha}^{-}{ }^{-}\right)$ & 470 & 470 & 470 & 550 & 550 & 550 \\
Seasonal water applied, $\left(\mathrm{m}^{3} \mathrm{ha}^{-1}\right)$ & 3510 & 4560 & 6510 & 3950 & 5122 & 7122 \\
\hline
\end{tabular}

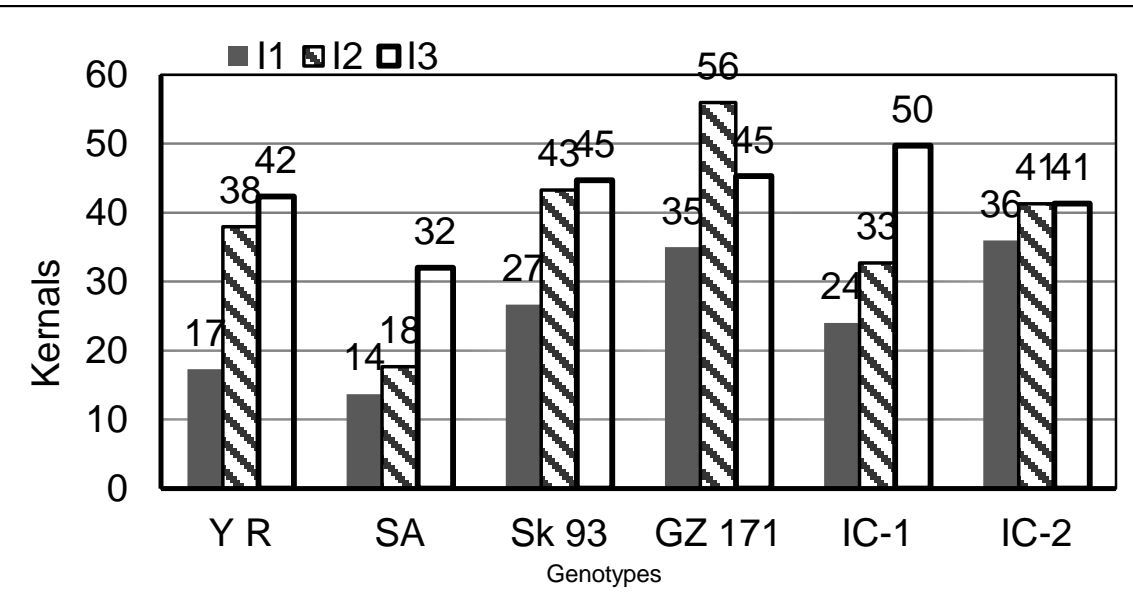

Fig 3. Kernals spik ${ }^{-1}$ of six wheat genotypes as affected by irrigation regime in first season (LSD at $5 \%$ level for interaction 10.2 ).

Table 4. Analysis of variance " $P$ " values for selected sources of variation for characters measured on six wheat genotypes with three irrigation treatments for 2 years.

\begin{tabular}{llllllll}
\hline SOV & $\mathrm{DH}$ & $\mathrm{PH}$ & $\mathrm{Sm}^{-2}$ & $\mathrm{KS}^{-1}$ & $\mathrm{KW}$ & $\mathrm{GY}$ & WUE \\
\hline Year (Y) & 0.00 & 0.00 & 0.00 & 0.00 & 0.00 & 0.00 & 0.00 \\
Irrigation (I) & - & 0.00 & 0.00 & 0.00 & 0.00 & 0.00 & 0.00 \\
YI & - & 0.00 & 0.18 & 0.01 & 0.02 & 0.00 & 0.00 \\
Genotypes & 0.00 & 0.00 & 0.00 & 0.00 & 0.00 & 0.00 & 0.00 \\
YG & 0.39 & 0.00 & 0.00 & 0.00 & 0.00 & 0.06 & 0.02 \\
IG & 0.34 & 0.03 & 0.09 & 0.04 & 0.15 & 0.00 & 0.03 \\
Y IG & 0.07 & 0.01 & 0.08 & 0.16 & - & 0.01 & 0.02 \\
\hline CV\% & 2.9 & 9.4 & 22.6 & 15.1 & 16.9 & 21.5 & 21.4 \\
\hline
\end{tabular}

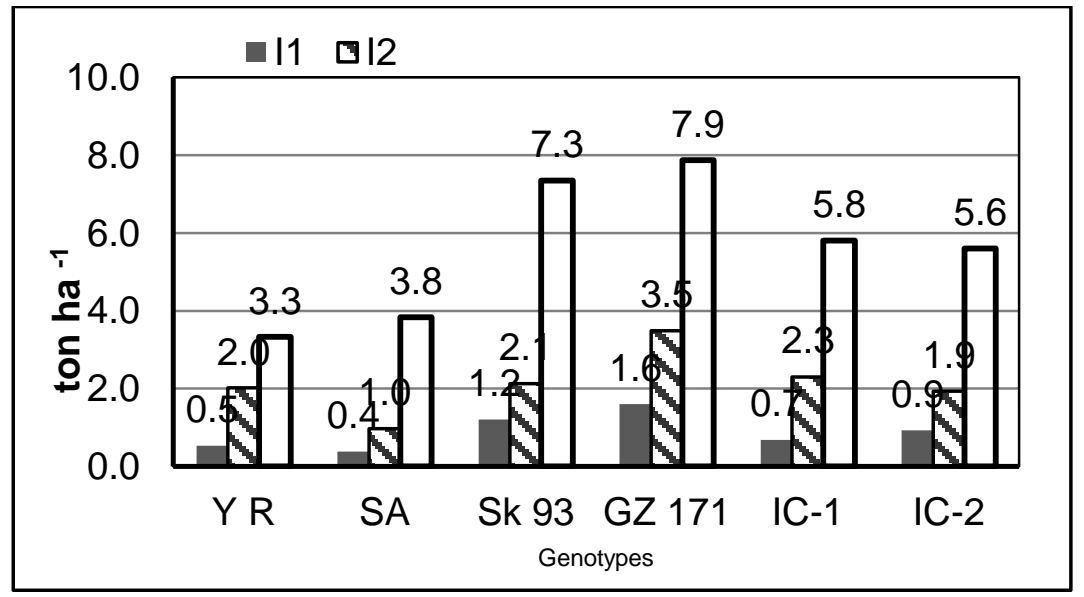

Fig 4. Grain yield of six wheat genotypes as affected by irrigation regime in first season (LSD at $5 \%$ level for interaction, 1.1). 
Table 5. Effect of irrigation regime, genotypes and their interaction on day to heading, plant height spikes $\mathrm{m}^{-2}$ and kernels spike ${ }^{-1}$ for bread wheat genotypes in 2009/10 and 2010/11 seasons.

\begin{tabular}{|c|c|c|c|c|c|c|c|c|}
\hline \multirow[t]{2}{*}{ Treatment } & \multicolumn{2}{|l|}{$\mathrm{DH}$} & \multicolumn{2}{|l|}{$\mathrm{PH}$} & \multicolumn{2}{|l|}{$\mathrm{Sm}^{-2}$} & \multicolumn{2}{|l|}{$\mathrm{KS}^{-1}$} \\
\hline & $09-10$ & $10-11$ & $09-10$ & $10-11$ & $09-10$ & $10-11$ & $09-10$ & $10-11$ \\
\hline \multicolumn{9}{|l|}{ Irrigation } \\
\hline $\mathrm{I}_{1}$ & 68.2 & 70.3 & $47.4 c^{*}$ & $44.8 c$ & $197.5 c$ & $345.0 c$ & $25.4 c$ & $45.6 c$ \\
\hline $\mathrm{I}_{2}$ & 68.0 & 70.5 & $59.4 b$ & $61.9 \mathrm{~b}$ & $322.7 b$ & $548.6 b$ & $38.2 b$ & $50.1 b$ \\
\hline $\mathrm{I}_{3}$ & 67.9 & 70.7 & $63.6 a$ & $76.7 a$ & $423.4 a$ & $631.1 \mathrm{a}$ & $42.6 a$ & $54.3 a$ \\
\hline$P$ Value & - & - & 0.000 & 0.003 & 0.003 & 0.000 & 0.000 & 0.006 \\
\hline Reduction\% (I1vs I3) & -0.44 & 0.28 & 25.5 & 41.6 & 53.4 & 45.3 & 40.4 & 16.0 \\
\hline \multicolumn{9}{|l|}{ Genotypes } \\
\hline Yecora Rojo & $59.9 e$ & $63.0 \mathrm{e}$ & $48.0 c$ & $48.2 d$ & $280.9 b$ & $500.6 b$ & $32.6 c$ & $41.9 d$ \\
\hline Sama & $76.1 a$ & $77.2 \mathrm{a}$ & $63.6 a$ & $83.9 a$ & $271.9 b$ & $657.8 \mathrm{a}$ & $21.1 d$ & $46.1 \mathrm{~cd}$ \\
\hline Sakha 93 & $63.9 d$ & $67.0 d$ & $55.2 b$ & $56.1 c$ & $372.7 a$ & $432.8 b$ & $38.2 b c$ & $47.1 \mathrm{~cd}$ \\
\hline Giza 171 & $67.0 c$ & $69.8 c$ & $66.8 \mathrm{a}$ & $66.2 b$ & $276.4 b$ & $414.4 b$ & $45.4 a$ & $50.9 b c$ \\
\hline IC-1 & $69.7 b$ & $73.0 \mathrm{~b}$ & $51.7 \mathrm{bc}$ & $56.7 c$ & $373.2 b$ & $522.8 b$ & $35.4 b c$ & $59.1 a$ \\
\hline IC-2 & $71.7 \mathrm{~b}$ & $73.0 \mathrm{~b}$ & $55.6 b$ & $55.8 c$ & $312.2 \mathrm{ab}$ & $521.1 b$ & 39.6ab & $54.8 \mathrm{ab}$ \\
\hline$P$ Value & 0.000 & 0.000 & 0.000 & 0.000 & 0.000 & 0.000 & 0.000 & 0.000 \\
\hline IxG $P$ value & - & 0.09 & 0.07 & 0.017 & 0.002 & 0.001 & 0.009 & - \\
\hline
\end{tabular}

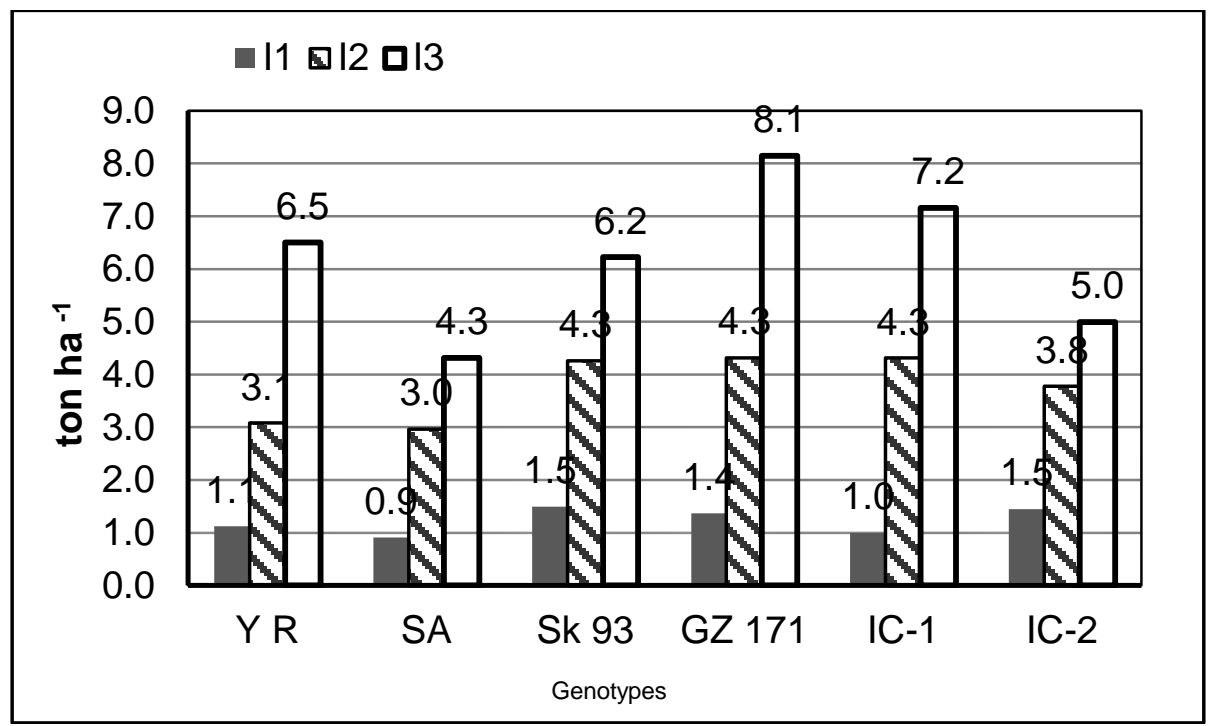

Fig 5. Grain yield of six wheat genotypes as affected by irrigation regime in second season (LSD at 5\% level for interaction, 1.3).

Table 6. Effect of irrigation regime, genotypes and their interaction on yield characters and WUE for bread wheat genotypes in 2009/10 and $2010 / 11$ seasons.

\begin{tabular}{|c|c|c|c|c|c|c|}
\hline \multirow[t]{2}{*}{ Treatment } & \multicolumn{2}{|c|}{$\mathrm{KW}$} & \multicolumn{2}{|c|}{ GY } & \multicolumn{2}{|c|}{ WUE } \\
\hline & $09-10$ & $10-11$ & $09-10$ & $10-11$ & $09-10$ & $10-11$ \\
\hline \multicolumn{7}{|l|}{ Irrigation } \\
\hline$I_{1}$ & $23.1 b^{*}$ & 39.2 & $0.9 c$ & $1.2 \mathrm{c}$ & $0.28 c$ & $0.34 b$ \\
\hline$I_{2}$ & $29.4 a$ & 41.7 & $2.1 b$ & $3.8 b$ & $0.51 b$ & $0.79 a$ \\
\hline$I_{3}$ & $32.2 \mathrm{a}$ & 40.6 & $5.6 a$ & $6.2 \mathrm{a}$ & $0.94 a$ & $0.93 a$ \\
\hline$P$ Value & 0.003 & - & 0.000 & 0.000 & 0.000 & 0.002 \\
\hline Reduction\% (I1vs. I3) & 28.3 & 3.4 & 84.1 & 80.3 & 70.2 & 63.4 \\
\hline \multicolumn{7}{|l|}{ Genotypes } \\
\hline Yecora Rojo & $26.8 \mathrm{ab}$ & 47.3ab & $2.0 \mathrm{~d}$ & $3.6 b$ & $0.42 d$ & $0.67 b$ \\
\hline Sama & $29.9 a$ & $30.1 d$ & $1.7 d$ & $2.7 c$ & $0.32 \mathrm{e}$ & $0.49 c$ \\
\hline Sakha 93 & $22.8 b$ & $44.3 b$ & $3.6 b$ & $4.0 \mathrm{ab}$ & $0.72 b$ & $0.75 a b$ \\
\hline Giza 171 & $30.6 a$ & $50.6 a$ & $4.3 a$ & $4.6 a$ & $0.88 a$ & $0.83 a$ \\
\hline IC-1 & $30.2 a$ & $33.4 \mathrm{~cd}$ & $2.9 b c$ & $4.2 \mathrm{ab}$ & $0.58 c$ & $0.75 a b$ \\
\hline IC-2 & $29.1 a$ & $37.0 \mathrm{c}$ & $2.8 \mathrm{c}$ & $3.4 b c$ & $0.55 c$ & $0.64 b$ \\
\hline$P$ Value & 0.000 & 0.000 & 0.000 & 0.000 & 0.000 & 0.000 \\
\hline IxG $P$ Value & 0.15 & - & 0.000 & 0.010 & 0.009 & 0.08 \\
\hline
\end{tabular}


Table 7. Mean values of drought susceptibility index (DSI) in 2009/2010 and 2010/2011 seasons (severe stress vs. normal irrigation) and average of two seasons.

\begin{tabular}{llll}
\hline Genotypes & $2009 / 10$ & $2010 / 11$ & Mean of 2-years \\
\hline Yecora Rojo & 1.00 & 1.03 & 1.01 \\
Sama & 1.07 & 0.98 & 1.02 \\
Sakha 93 & 0.99 & 0.95 & 0.97 \\
Giza 171 & 0.95 & 1.00 & 0.97 \\
IC-1 & 1.05 & 1.07 & 1.06 \\
IC-2 & 0.99 & 0.88 & 0.94 \\
\hline
\end{tabular}

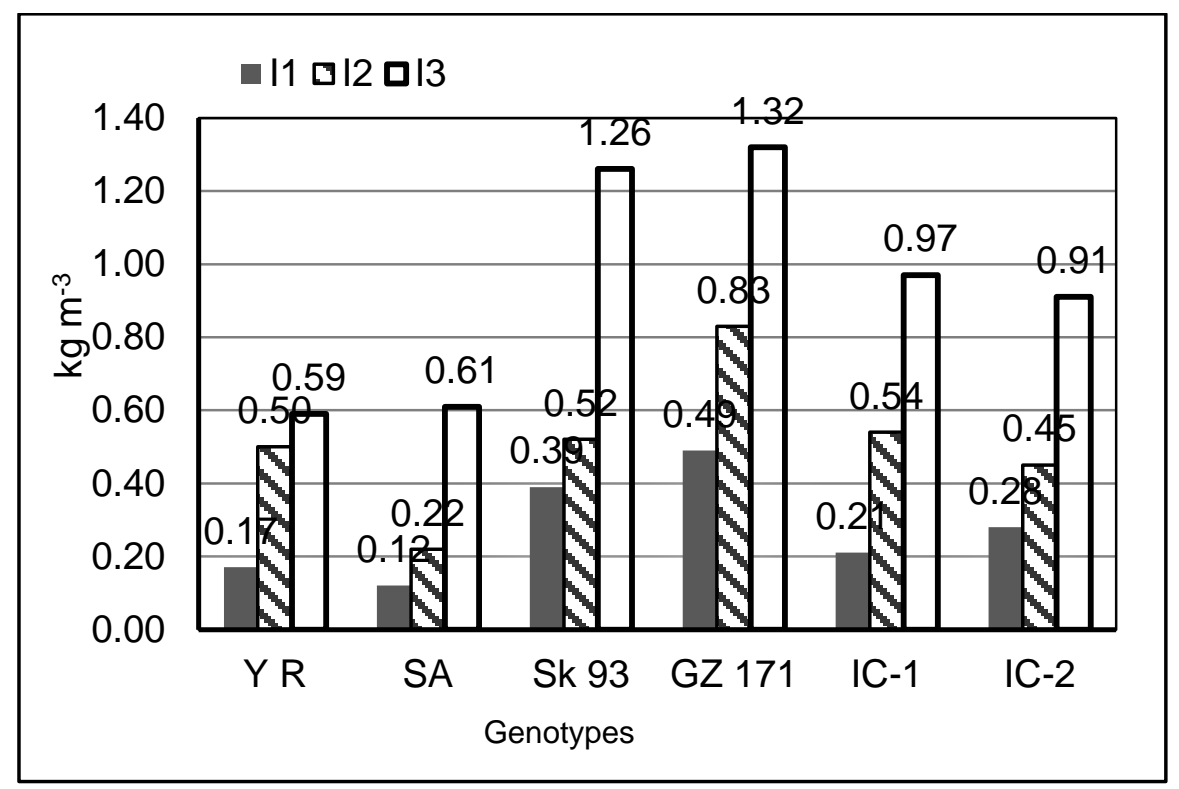

Fig 6. WUE of six wheat genotypes as affected by irrigation regime in first season (LSD at $5 \%$ level for interaction, 0.2 ).

\section{Interactional effects}

We only discuss the significant interactional effect. The interaction between genotypes and water treatments had significant effects on plant height in the 2 nd season, spikes $\mathrm{m}^{-2}$ in 1 st season, kernels spike ${ }^{-1}$ in the 1 st season, grain yield in two seasons and WUE in 1st season (Tables 5-6 and Fig 1-7). These results revealed that the genotypes responded differently to water regime for these traits and reflected the possibility of selecting the most suitable genotypes. Alizadeh and Ghaderi, (2006) reported that, the presence and absence of interactions among and between the factors strongly depends on the behavior of genotypes in trial. In most studies there were significant genotype $\times$ environment interactions for most characters (Menshawy and Hagrass, 2008; Jatoi et al., 2011; Mushekwa, 2012 and Ali et al., 2013). On the other hand, insignificant differences among irrigation treatments and genotypes interaction were found for some traits (Taheri et al., 2011; Gholamin et al., 2010).

Results in Fig. 1 indicated a decline in plants height in all varieties under stressed condition. The decrease in plant height in all varieties in response to drought stress may be due to decrease in relative turgidity and dehydration of protoplasm which is associated with a loss of turgor and reduced expansion of cell and cell division (Arnon, 1972). Yecora Rojo was the shortest genotype under all irrigation treatments, while Sama genotype was vice versa. Mushekwa (2012) reported that, in low water application, plant height was identified as the most important traits that explained variation in WUE of genotypes. Plant height differences among various cultivars are generally due to their genetic constitution (Musaddique et al., 2000; Sial et al., 2009, Gholamin et al., 2010).

Fig. 2 presented the interaction between genotypes and water treatments for number of spikes $\mathrm{m}^{-2}$ in 1 st season. Results showed that genotypes produced significantly lower spikes number $\mathrm{m}^{-2}$ under drought stress conditions. All genotypes grown at severe water stress had lowest spikes $\mathrm{m}^{-2}$. We suggest that the genotypes did not produce tillers due to severe water stress condition, hence only main spike contributed to total yield per plant. Number of spikes $\mathrm{m}^{-2}$ ranged from 165 (YR under I1) to 540 (IC-1 under control). Similarly numbers of kernels spike ${ }^{-1}$ were also reduced with an increase in drought stress (Fig.3). Numbers of kernels spike ${ }^{-1}$ ranged from 14 (Sama under I1) to 56 (Giza 171 under 12). Giza 171 had high numbers of kernels spike ${ }^{-1}$ in most cases. This was in line with studies of Ali et al. (2013), who reported that 
water stress affect all the yield components, mainly the number of grains per spike and the number of spikes per plant. Elhafid et al. (1998) demonstrated that drought stress results in reduced pollination and number of grains per spike. Number of grains per ear and thousand kernel weight are important yield components in wheat which are significantly influenced by the prevailing growing conditions and the genotype (Musaddique et al., 2000; Guendouz et al., 2012). Grain yield was significantly decreased by decreased amount of irrigation water (Fig. 4-5). The effect of different water stress levels was clear on grain yield of wheat genotypes. Water stress significantly reduced grain yield of all wheat genotypes and the highest reduction was found in I1. All the genotypes produced higher grain yield in control treatment, and significantly reduced at severe water stress. Water stress at all stages of plant growth affects the grain yield but when it takes place in critical stages of growth, grain yield is sharply decreased (Zamarud et al. 2013; Hanif et al. 2013; Kamran et al. 2014). The highest mean grain yield in two seasons under all irrigation treatments was obtained in genotype Giza 171, while Sama showed vice versa. Genotype 'Giza 171' yielded higher than the other genotypes under both normal irrigation and drought stress condition in two seasons. This was consistent with findings of Sayyah et al. (2012) who identified genotypes with good performance under both conditions. They also concluded that yield under stress condition was dependent on yield under non-stress condition. Fischer (1979) reported that cultivars having high yields under normal conditions usually better tolerate stress conditions and produce acceptable yields. In the first season, Giza171 produced statistically higher grain yield than the other genotypes under normal and moderate (12) stresses, except Sakha93 under normal condition and higher and statistically similar with Sakha 93, IC-1 and IC-2 under severe stress condition (Fig 4). In the second season, GiZa171 produced higher and statistically similar with Sakha 93 and IC-1 under all irrigation treatment, except for Sakha93 under normal condition which showed statistically lower grain yield than GiZa171 (Fig.5). The superior grain yield belonged to Giza 171 at all conditions, followed by Sakha 93 and IC-1 under drought stress. Nouri-Ganbalani et al. (2009) reported that, grain yield of any genotype is influenced by a complex of different morphological, physiological and phenological traits of that genotype, which in turn was influenced by the soil moisture. Since the environmental conditions vary in different areas, therefore, the response of plant traits to the drought stress and expected grain yield also varies in different locations. This was in line with studies of other workers, though they identified genotypes with high grain yield under limited water supply and normal condition (Menshawy and Hagrass, 2008; Mushekwa, 2012; Ali et al., 2013; Kamran et al. 2014.). The researchers concluded that these traits could be used to select for wheat improvement under low water supply Water Utilization Efficiency (WUE) Water utilization efficiency data in the 1st season are presented in Fig.6. WUE, an important physiological character involved in adaptation of wheat to drought (Mushekwa, 2012). Normal irrigation treatment recorded the highest values in WUE, while reduced irrigation treatments recorded the low values. The highest values of water utilization efficiency were recorded by Giza 171, while the lowest values were recorded by Sama. Giza 171 was the best water utilization efficiency genotype under all conditions followed by Sakha 93 and IC-1. Genotypes that recorded high WUE were observed to have high kernels spike ${ }^{-1}$, kernel weight and grain yield. Genetic variability for WUE trait in wheat genotypes leads to success in identifying and selecting wheat lines and cultivars having morphological and physiological characteristics suitable for higher yields and water utilization efficiency (Lumpkin, 2011; Davies et al, 2011; Shamsi et al., 2010; Mushekwa, 2012). The drought susceptibility index (DSI) was used to estimate relative stress injury because it was accounted for variation in yield potential and stress intensity. Low drought susceptibility index (DSI $<1$ ) is synonymous to higher stress tolerance (Fisher and Mourer 1978). The DSI estimates varied among genotypes, from 0.95 (Giza 171) to 1.07 (Sama) in the 1st season and 0.88 (IC-2) to 1.07 (IC-1) in the 2 nd (Table 7). Sakha 93 and IC-2 had DSI values $<1$ in 1st and 2 nd seasons as well as mean of two seasons. Accordingly, these results confirmed that Giza 171, Sakha 93 and IC-2 can be labeled as drought-tolerant genotype, while IC-1 as drought-sensitive one. Farahat (2005) and Menshawy and Hagrass (2008) reported that Sakha 93 was drought-tolerant genotype. We believe that drought-tolerance characteristics might be transferred from Sakha 93 cultivar to Giza 171, a parent of these cultivars. In general, these results confirm that Giza 171 is one of genotypes with high yield potential in moisture stress conditions, especially in severe drought stress, while enjoys high WUE values with high yield in normal irrigation condition. These results coincide with the findings of Abd El-Moneim et al. (2010); Shamsi et al. (2010); Mushekwa (2012) and Ali et al. (2013).

\section{Materials and methods}

\section{Plant materials}

The plant materials for the study comprised of six bread wheat genotypes including two Egyptian cultivars (Sakha 93 and Giza 171), two ICARDA genotypes, Yocora Rojo (YR), and the local genotype (Sama) (Table 2). The Egyptian genotypes were drought and salt tolerance genotypes.

\section{Field experiments}

Field experiments were carried out during 2009/10 and 2010/11 wheat growing season at the Experimental Farm of the College of Agriculture and Veterinary Medicine, Qassim University, 26 $18^{\prime} \mathrm{N}$ latitude and 43ㅇ 58' E longitude, and $725 \mathrm{~m}$ above sea level, in central Saudi Arabia. The soil type of this farm is classified as sandy with $96.3 \%$ sand, $1.8 \%$ silt and $1.9 \%$ clay. Meteorological data at the experimental site during the growing seasons was presented in Table 1.

\section{Experimental design and data collection}

The wheat genotypes were evaluated under three adjacent irrigation regime treatments. The first treatment (I3) was given normal water irrigation (about $7000 \mathrm{m3} \mathrm{ha}{ }^{-1}$, according to recommendation for Qassim Region). The second (12) and third 
(I1) treatments were given $2 / 3$ and $1 / 3$ of water amount of the first treatment, respectively, started 30 days after sowing. A wide border surrounded each treatment to minimize the underground water permeability. The amount of applied irrigation water, total rainfall and seasonal water applied for each of the three irrigation treatments were measured (Table 3). Wheat genotypes were grown on fourth week of December using a randomized complete block design with three replications in a factorial experiment. Each plot consisted of four rows, $2 \mathrm{~m}$ long and $20 \mathrm{~cm}$ apart. Thus, the area of each plot was $1.6 \mathrm{~m}^{2}$. Seeds were drilled in the rows at the rate of 400 seeds $\mathrm{m}^{-2}$. All plots were irrigated equally at the beginning of the experiment in order to establish good germination and growth. Irrigation treatments were applied after one month from planting date. Water was applied by sprinkler irrigation system and the amounts of water applied were monitored using water flow meters. All other cultural practices were applied as recommended for wheat cultivation in Qassim Region. In both seasons, measurements were taken on, number of days to heading, plant height, number of spikes $\mathrm{m}^{-2}$, number of kernels spike ${ }^{-1}, 1000$-kernel weight, grain yield. Grain yield was estimated from the three central rows to eliminate the border effect of each plot and converted into ton hectare $^{-1}$. Water use efficiency (WUE), is expressed as the weight of grain yield to amount of seasonal water applied during the growing seasons. It was computed according to Doorenbos and Pruitt (1975) as follows: WUE = grain yield ( $\mathrm{kg}$ $\left.\mathrm{ha}^{-1}\right) /$ water applied ( $\left.\mathrm{m} 3 \mathrm{ha}^{-1}\right)$. Amount of water applied during the growing season was measured for each genotype based on maturity date (five days after maturity date). The drought susceptibility index (DSI) was used as a measure of drought tolerance in term of reduction in yield caused by unfavorable versus favorable environments. DSI was calculated for each genotype according to the formulas of Fisher and Maurer (1978):

DSI $=(1-y d / y p) / D$. Where: $y d=$ mean yield in drought environment, $Y p=$ mean yield in normal condition = potential yield, $D=$ drought stress intensity $=1-$ (mean yd of all genotypes / mean yp of all genotypes).

\section{Statistical analysis}

The collected data for all variables were statistically analyzed by "MSTATC" microcomputer program (MSTATC, 1990) via analysis of variance using randomized complete block design in factorial experiments. The means of irrigation regime and genotypes were obtained and differences were assessed with LSD at $5 \%$ level of probability.

\section{Conclusion}

The pervious results and discussion revealed that irrigation regime effect was highly significant for all traits, except days to heading. All studied characters were significantly decreased by lower amount of irrigation water. Existence of sufficient genetic variability among the genotypes for all the characters was observed. Giza 171, Sakha 93 and IC-1 recorded highest grain yield and WUE, based on average over irrigation treatments. Giza 171, Sakha 93 and IC-2 can be considered as drought stress tolerant genotypes.

\section{Acknowledgments}

The authors gratefully acknowledge the Deanship of Scientific Research at Qassim University for funding this project.

\section{References}

Abd El-Moneim DA, Mohamed IN, Belal AH, Atta ME (2010) Screening bread wheat genotypes for drought tolerance: Germination, radical growth and mean performance of yield and its components. Options Méditerranéennes, A. 95: 301305

Ahmed AAS, El-Morshidy MA, Kheiralla KA, Uptmoor R, Ali MA, Mohamed NEM (2014) Selection for drought tolerance in wheat population (Triticum aestivum L.) by independent culling levels. World J Agric Res. 2(2): 56-62.

Akçura M, Partigoç F, Kaya Y (2011) Evaluating of drought stress tolerance based on selection indices in turkish bread wheat landraces. J Anim Plant Sci. 21(4): 700-709.

Ali A, Ali N, Ullah N, Ullah F, Adnan M, Swati ZA (2013) Effect of Drought Stress on the Physiology and Yield of the Pakistani Wheat Germplasms. Int J Advance Res Technol. 2(7):419-430.

Alizadeh K, Ghaderi J (2006) Variation of nitrogen uptake efficiency in local landraces of wheat in Mahabad. Iran J Agric Sci. 2(3): 122-124.

Andarab SS (2013) Study of correlation among yield and yield components affecting traits on bread wheat under drought stress and non-stress conditions. Annal Biolo Res. 4(5): 286289.

Arnon I (1972) Crop Production in Dry Regions, Background and Principles. N. Polunin, editor. Leonard Hill Book, London, Vol. 1, pp. 203-211.

Bacon MA (2004) Water use-efficiency in plant biology. In: Bacon M.A. (Ed): Water use efficiency in plant biology. pp: 126. Oxford: Blackwell Publishing.

Balouchi RH (2010) Screening wheat parents of mapping population for heat and drought tolerance, detection of wheat genetic variation. Int J Biol Life Sci. 6: 56-66.

Davies WJ, Zhang J, Yang J, Dodd IC (2011) Novel Crop Science to improve yield and resource use efficiency in water limited agriculture: Foresight Project on Global food and farming futures. J Agric Sci. 149: $123-131$

Doorenbos J, Pruitt WO (1975) Crop water requirements, irrigation and drainage paper, No.24, FAO, Rome. Italy.

Ehdaie B, Waines JG, Hall AE (1988) Differential responses of landrace and improved spring wheat genotypes to stress environments. Crop Sci. 28: 838-842.

Ehdaie B (1995) Variation in water-use efficiency and its components in wheat: II. Pot and Field Experiments. Crop Sci. 35: $1617-1626$.

Elhafild R, Smith DH, Karrou M, Samir K (1998) Morphological attributes associated with early season drought tolerance in spring wheat in a Mediterranean environment. Euphytica. 101: 273-282. 
Fischer RA, Maurer R (1978) Drought resistance in spring wheat cultivars. I. Grain yield responses. Aust J Agric Res. 29: 897-912.

Fischer RA (1979) Growth and water limitation to dryland wheat yield in Australia: a physiological frame work. J Aust Inst Agric Sci. 45:83-94.

Gholamin R, Zaeifizadeh M, Khayatnezhad M, Jomaati-eSomarin S, Zabihi-e-Mahmoodabad R (2010) Study of drought tolerance in durum wheat genotypes. Am-Euras J Agric Environ Sci. 9(5): 465 - 469.

Guendouz A, Guessoum S, Maamari K, Hafsi M (2012) Effects of supplementary irrigation on grain yield, yield components and some morphological traits of durum wheat (Triticum Durum Desf.) cultivars. Adv Environ Biol. 6(2): 564 - 572.

Guttieri MJ, Stark JC, O'Brien K, Souza E (2001) Relative sensitivity of spring wheat grain yield and quality parameters to moisture deficit. Crop Sci. 41: 327-335.

Hanif R, Naeem-Ud-D., Subhani A, Rabbani G, Tariq M, Iqbal MS, Koukab M (2013) Performance Based Evaluation of Different Genotypes of Mungbean (Vigna Radiata) Under Rainfed Conditions of Chakwal. J Agri-Food Appl Sci. 1 (1): 1315.

Jatoi WA, Baloch MJ, Kumbhar MB, Khan NU, Kerio MI (2011) Effect of water stress on physiological and yield parameters at anthesis stages in elite spring wheat cultivars. Sarhad J Agric. 27(1): 59-65

Kamran M, Naeem MK, Ahmad M, Shah MKN, Iqbal MS (2014) Physiological responses of Wheat (Triticum aestivum L.) against drought stress. Am J Res Commun. www.usajournals.com ISSN: 2325-4076.

Karamanos AJ, Economou G, Papastavrou A, Travlos IS (2012) Screening of Greek wheat landraces for their yield responses under arid conditions. Int J Plant Prod. 6 (2): $225-238$.

Khakwani A, Dennett MD, Munir M (2011) Drought tolerance screening of wheat varieties by inducing water stress conditions. Songklanakarin J Sci Technol. 33 (2): 135-142.

KulKarni M, Borse T, Czech SC (2008) Mining anatomical traits: A novel modelling approach for increased water use efficiency under drought conditions in plants. J Genet Plant Breed. 44(1): 11-21.

Lumpkin AT (2011) Wheat - Global Alliance for Improving food security and the Livelihoods of the Resource-poor in the Developing World. Proposal submitted by CIMMYT and ICARDA to the CGIAR Consortium Board in collaboration with Biodiversity, ICRISAT, IFPRI, ILIRI and IWMI. CIMMYT

Mahmood A, Mian MA, Ihsan M, ljaz M, Rabbani G, Iqbal MS (2013) Chakwal-50: A high yielding and disease resistant wheat variety for rainfed region. J Anim Plant Sci. 23(3): 833839.

Menshawy AMM, Hagras AAI (2008) Evaluation of Some Bread Wheat Genotypes Under Normal and Reduced Irrigation. The frist International On Environmentel Studies Research, Minufiy Universtiy-Sadat Branch, Egypt,7-9April 2008 PP.312323.
Miranzadeh H, Emam Y, Pilesjo P, Seyyedi H (2011) Water use efficiency of four dryland wheat cultivars under different levels of nitrogen fertilisation. J Agri Sci Tech. 13: 843 - 854.

Nouri-Ganbalani A, Nouri-Ganbalani G, Hassanpanah D (2009) Effects of drought stress condition on the yield and yield components of advanced wheat genotypes in Ardabil, Iran. J Food Agric Environ. 7 (3\&4): 228-234.

Okuyama LA, José LCF, Neto FB (2004) Correlation and path analysis of yield and its components and plant traits in wheat. Ciência Rural, Santa Maria 34(6): 1701-1708.

Pireivatlou AS, Yazdansepas A (2008) Evaluation of wheat (Triticum aestivum L.) genotypes under pre- and postanthesis drought stress conditions. J Agric Sci Technol. 10: 109-121.

Sayyah SS, Ghobadi M, Mansoorifar S, Zebarjadi AR (2012) Evaluation of drought tolerance in some wheat genotypes to post-anthesis drought stress. J Agric Sci. 4(11): 248 -256.

Shamsi K, Petrosyan M, Noor-mohammadi G, Haghparast R (2010) Evaluation of grain yield and its components in three bread wheat cultivars under drought stress. J Anim Plant Sci. 9(1): 1117- 1121.

Sial MA, Dahot MU, Arain MA, Markhand GS, Mangrio SM, Naqvi MH, Laghari KA, Mirbahar AA (2009) Effect of water stress on yield and yield components of semi-dwarf bread wheat (Triticum aestivum. L). Pak J Bot. 41(4): 1715 - 1728.

Taheri S, Saba J, Shekari F, Abdullah TL (2011) Effects of drought stress condition on the yield of spring wheat (Triticum aestivum L) lines. Afr J Biotechnol. 10(80): 1833918348.

Tahmasebi S, Khodambashi M, Rezai A (2007) Estimation of genetic parameters for grain yield and related traits in wheat using diallel analysis under optimum and moisture stress conditions. J Sci Technol Agric Natur Resour. 11(1A): 241.

Thompson JA, Chse DL (1992) Effect of limited irrigation on growth and yield of semi-dwarf wheat in southern New Wales. Aust J Exp Agric. (32): 725-730.

Yong'an L, Quanwen D, Zhigou C, Deyong Z (2010) Effects of drought on water use efficiency, agronomic traits and yield of spring wheat landraces and modern varieties in Northwest China. Afric J Agric Res. 5(13): 1598 - 16.

Zamurrad M, Tariq M, Shah FH, Subhani A, Ijaz M, Iqbal MS, Koukab M (2013) Performance Based Evaluation of Groundnut Genotypes under Medium Rainfall Conditions of Chakwal. J Agri-Food Appl Sci. 1 (1): 9-12.

Zhang B, Li FM, Huang G, Cheng ZY, Zhang Y ( 2006) Yield performance of spring wheat improved by regulated deficit irrigation in arid area. Agric Water Manag. (79): 28-42.

Zhang X, Chen S, Sun H, Wang Y, Shao L (2010) Water use efficiency and associated traits in winter wheat cultivars in the North China Plain. Agric Water Manag. 97: 1117-1125. 